\title{
Middle Jurassic (Callovian) cyclostome bryozoans from the Tethyan tropics (Matmor Formation, southern Israel)
}

\author{
MARK A. WiLSON, StephaNiE BOSCH \& PAUL D. TAYLOR
}

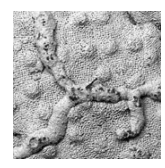

\begin{abstract}
A tropical Jurassic bryozoan fauna is described here for the first time. The Matmor Formation (Callovian, upper Peltoceras athleta Zone) contains six cyclostome bryozoan species in five genera. Four of these species are new: Microeciella yoavi, Idmonea snehi, Hyporosopora nana, and Hyporosopora negevensis. The Matmor Formation was deposited on a shallow shelf near the palaeoequator on the southwestern margin of the Tethys Ocean, within the Ethiopian Province of the Tethyan Faunal Realm. The Matmor bryozoans share genera with contemporary, non-tropical faunas in Europe, having the most similarities with Callovian assemblages in Poland. The low species richness of the Matmor bryozoan fauna is not unusual for the Jurassic but they do appear to be less abundant than contemporaneous fully marine bryozoan faunas from higher palaeolatitudes. The unusually small zooids of the Matmor bryozoans may be a function of the temperature-size rule because this fauna developed in shallow, warm, tropical waters. $\bullet$ Key words: Bryozoa, Cyclostomata, Callovian, Jurassic, Israel.
\end{abstract}

\begin{abstract}
WiLSON, M.A., BOSCH, S. \& TAYLOR, P.D. 2015. Middle Jurassic (Callovian) cyclostome bryozoans from the Tethyan tropics (Matmor Formation, southern Israel). Bulletin of Geosciences 90(1), 51-63 (8 figures, 1 table). Czech Geological Survey, Prague. ISSN 1214-1119. Manuscript received April 4, 2014; accepted in revised form September 22, 2014; published online December 3, 2014; issued January 26, 2015.
\end{abstract}

Mark A. Wilson (corresponding author) \& Stephanie Bosch, The College of Wooster, Department of Geology, Wooster, Ohio 44691 USA; mwilson@wooster.edu, sbosch14@wooster.edu Paul D. Taylor, Natural History Museum, Department of Earth Sciences, Cromwell Road, London SW7 5BD, United Kingdom; ptaylor@nhm.ac.uk

The Middle Jurassic was a time of diversification and innovation in the Phylum Bryozoa, especially among the cyclostomes (Taylor \& Ernst 2008). Most of the data on Jurassic bryozoan faunas comes from Europe (see, for examples, Walter 1970; Hara \& Taylor 1996, 2009; Taylor 2009; Viskova 2006, 2007, 2008, 2009; Zatoń \& Taylor 2009, 2010; Zatoń et al. 2013) with a few North American occurrences (see Cuffey \& Ehleiter 1984, Taylor \& Wilson 1999), which were situated at palaeolatitudes to the north of the Jurassic tropics. Sclerobionts (hard substrate dwellers; Taylor \& Wilson 2002) in general commenced a significant diversification in the Callovian and began to resemble their modern counterparts (Zatoń \& Vinn 2011). This was also a time when marine communities were consolidating following the first pulse of the Mesozoic Marine Revolution (Vermeij 1977, 2008; Aberhan et al. 2006). A bryozoan fauna from the tropics of the Jurassic is described here for the first time, adding to the single species described by Newton (1921) from the ?Upper Jurassic of Bachain, near Riyadh, Saudi Arabia. This provides new information about latitudinal bryozoan diversity gradients in the Jurassic, and contributes to a global perspective on Jurassic marine community evolution.
Only recently have geologists begun to systematically describe and interpret the palaeoecological and palaeogeographical contexts of Jurassic tropical marine faunas. Thus far, most of the investigated fossils have been from shallow Tethyan shelf deposits in the Middle East (e.g., Feldman \& Brett 1998; Pandey et al. 2000; Wilson et al. 2008, 2010; Ausich \& Wilson 2012; Feldman et al. 2012). The fossils in this region are well exposed and quite well preserved, and they can be collected in a well-defined lithostratigraphic and biostratigraphic framework.

\section{Geological setting}

All the bryozoans in this study come from a single unit of fossiliferous marl in the Matmor Formation (Callovian) exposed in the Matmor Hills of Hamakhtesh Hagadol (an erosional basin similar to a breached anticline; Avni 2001) in southern Israel. The Matmor Formation is approximately 120 metres of lagoonal and reefal marls and limestones lying conformably above the Zohar Formation (also Callovian) and disconformably below the Lower Cretaceous 


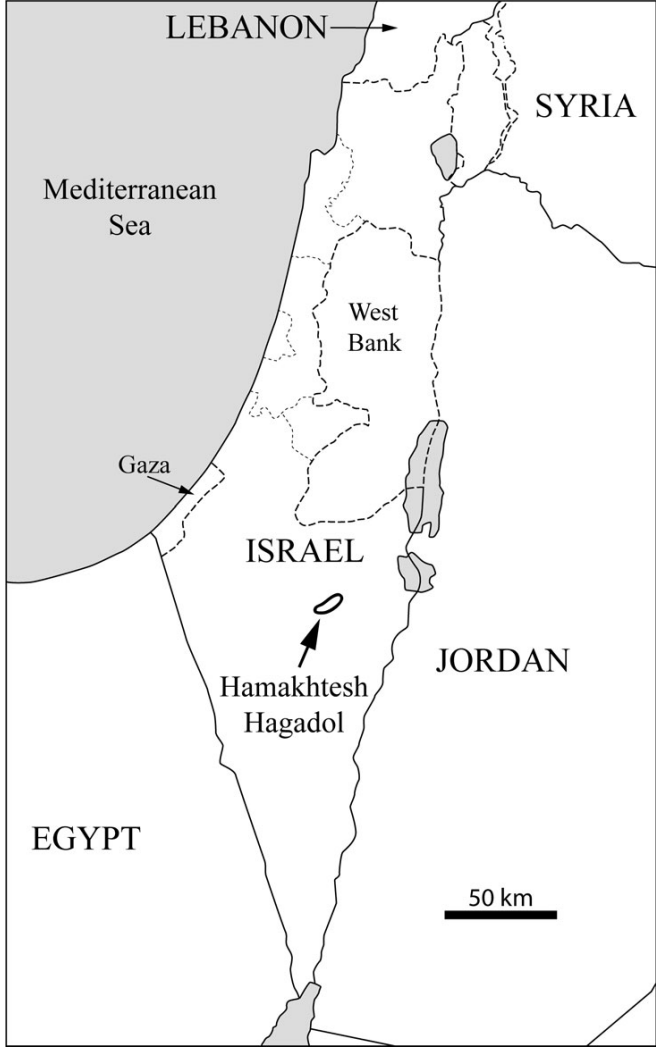

Figure 1. Location of field site Hamakhtesh Hagadol in southern Israel. See Table 1 for specific localities within the makhtesh.

(Aptian) Hatira Formation (Hirsch \& Roded 1997). Originally considered as upper Callovian and lower Oxfordian (e.g., Hudson 1958), ammonites (Gill et al. 1985, Cariou et al. 1997, Hirsch et al. 1998) and foraminifera (Grossowicz et al. 2000) now show that the entire Matmor Formation is Callovian. The lower 30 metres of the Matmor (subunits 43-52; Goldberg 1963) belong to the Peltoceras athleta Zone, and the subunits above are in the Quenstedtoceras (Lamberticeras) lamberti Zone of the Upper Callovian (Hirsch et al. 1998).

The Matmor Formation was deposited near the palaeoequator during late Callovian times on the southern margin of the Tethys (Golonka 2004). This was within the Ethiopian Province of the Tethyan Faunal Realm (Feldman et al. 2001). The horizon from which the bryozoans described here were collected (subunit 51; Goldberg 1963) was part of the J40 major maximum flooding event across the Arabian Platform at approximately $163 \mathrm{Ma}$ (Sharland et al. 2004), which was a result of an apparent global rise in sea level (Wierzbowski et al. 2009). This transgression facilitated the development of numerous calcareous sponge and coral patch reefs with lagoonal marls throughout the region (Haq \& Al-Qhatani 2005).

The bryozoans in the Matmor Formation are accompanied by a rich shallow marine fauna of sponges (Wood

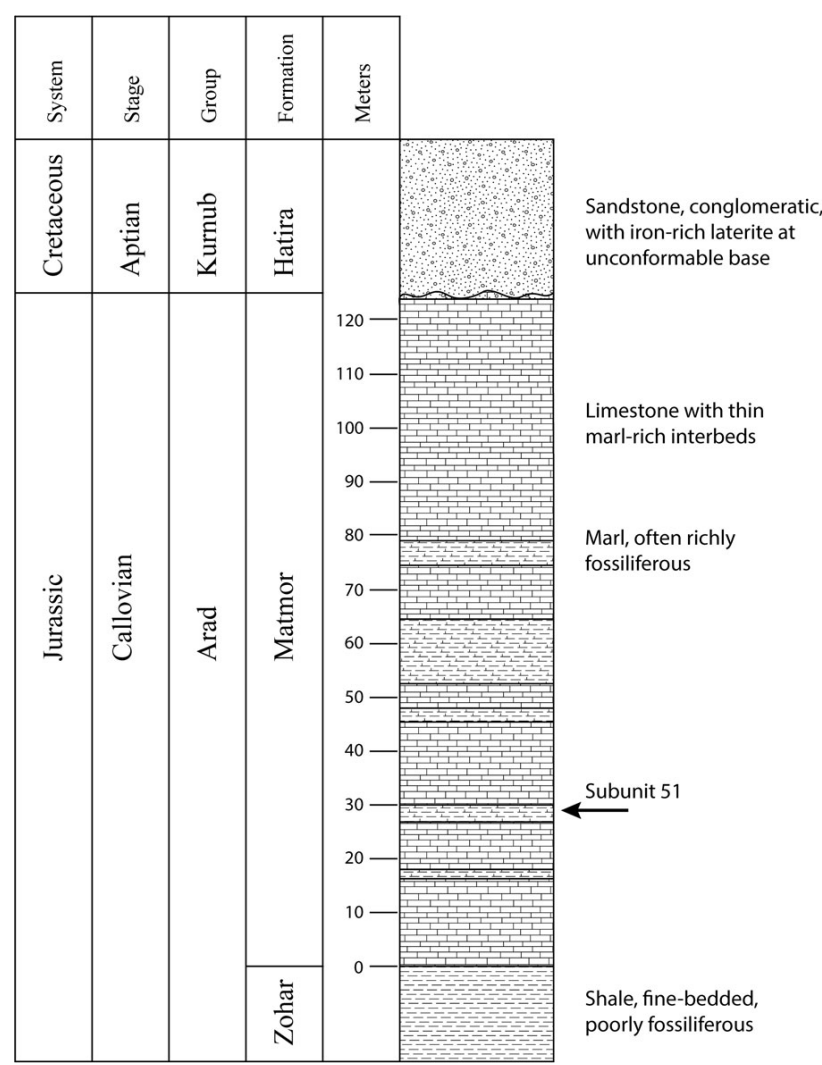

Figure 2. Stratigraphic column of the Matmor Formation exposed within Hamakhtesh Hagadol (Fig. 1). All the bryozoans described in this study were collected from Subunit 51 of Goldberg (1963).

Table 1. Locations of the bryozoans collected for this study at Hamakhtesh Hagadol, southern Israel (Fig. 1). All are in subunit 51 (Goldberg 1963) of the Matmor Formation, which is 25-30 metres above the base.

\begin{tabular}{|c|c|}
\hline Location \# & Coordinates \\
\hline $\mathrm{C} / \mathrm{W}-172$ & $\mathrm{~N} 30.93369^{\circ}$, E $34.97588^{\circ}$ \\
\hline C/W-173 & $\mathrm{N} 30.92907^{\circ}$, E $34.97295^{\circ}$ \\
\hline $\mathrm{C} / \mathrm{W}-247$ & $\mathrm{~N} 30.95040^{\circ}$, E $35.00758^{\circ}$ \\
\hline $\mathrm{C} / \mathrm{W}-366$ & N $30.94919^{\circ}$, E $35.01109^{\circ}$ \\
\hline $\mathrm{C} / \mathrm{W}-371$ & N $30.94220^{\circ}$, E $34.98131^{\circ}$ \\
\hline C/W-600 & N $30.93837^{\circ}$, E $34.979069^{\circ}$ \\
\hline C/W-602 & $\mathrm{N} 30.93549^{\circ}, \mathrm{E} 34.97683^{\circ}$ \\
\hline C/W-608 & $\mathrm{N} 30.94916^{\circ}, \mathrm{E} 35.01110^{\circ}$ \\
\hline C/W-609 & $\mathrm{N} 30.929081^{\circ}, \mathrm{E} 34.972984^{\circ}$ \\
\hline
\end{tabular}

1987, 1999), corals (Wilson et al. 2010), brachiopods (Feldman et al. 2001), bivalves (Hirsch 1979), gastropods (Reiner 1968), ammonites (Gill \& Tinant 1975, Gill et al. 1985, Lewy 1983) and crinoids (Ausich \& Wilson 2012). The sclerobionts (hard substrate dwellers; Taylor \& Wilson 2003) have lately been described in some detail. They include serpulid and sabellid tubes (Vinn \& Wilson 2010), thecideide brachiopods (Krawczyński \& Wilson 2011), and a variety of borings (Wilson et al. 2008, 2010). 
Almost all the bryozoans described in this paper encrust pluricolumnals and holdfasts of the large articulate crinoid Apiocrinites negevensis Ausich \& Wilson, 2012. A few are found on pluricolumnals of a smaller crinoid, Apiocrinites feldmani Wilson et al., 2014. The bryozoans appear to be post mortem encrusters on the crinoids because they often extend over articulating surfaces.

\section{Localities, methods and materials}

The bryozoans described here are from subunit 51 (Goldberg 1963) of the Matmor Formation (Middle Jurassic, Callovian, upper Peltoceras athleta Zone) exposed in the Matmor Hills of Hamakhtesh Hagadol, southern Israel (Fig. 1). Subunit 51 is $28-30$ metres above the base of the formation (Fig. 2). Table 1 lists the specific localities with location numbers and coordinates.

Approximately 130 bryozoan colonies were found encrusting primarily crinoids (Apiocrinites negevensis and $A$. feldmani), with a few on echinoids, bivalves and ammonites. These were cleaned in an ultrasonic bath and examined with a binocular microscope. Well-preserved specimens were measured with a Nikon SMZ1500 videomicroscope and CellSans Standard imaging software. The most representative and diagnostic specimens were further studied and imaged using a LEO 1455VP low vacuum scanning electron microscope housed at the Natural History Museum, London.

Following the definitions of Zaton et al. (2013, p. 838), we use the term "gonozooid" for the entire fertile zooid and "brood chamber" for the distal, expanded portion of the gonozooid in which the embryos would have been housed.

Type and figured specimens are deposited in the fossil collections of the Natural History Museum, London (NHMUK).

\section{Systematic palaeontology}

Order Cyclostomata Busk, 1852

Family Stomatoporidae Pergens \& Meunier, 1886

\section{Genus Stomatopora Bronn, 1825}

Type species. - Alecto dichotoma Lamouroux, 1821, by monotypy; Bathonian of Calvados, France.

\section{Stomatopora aff. dichotomoides (d'Orbigny, 1850)} Figure 3A-D

Material. - Numerous colonies encrusting biogenic debris, especially ossicles of the crinoid Apiocrinites (NHMUK BZ 7720, 7721, 7723).
Measurements. - Autozooid width (proximal) 0.06-0.22 mm ( mean $=0.12 \mathrm{~mm} ; \mathrm{n}=68)$; autozooid width (distal) $0.11-0.37 \mathrm{~mm}$ (mean $=0.18 \mathrm{~mm} ; \mathrm{n}=68)$; autozooid length 0.31-0.64 mm (mean $=0.47 \mathrm{~mm} ; \mathrm{n}=40)$; longitudinal aperture diameter $0.04-0.10 \mathrm{~mm}$ (mean $=0.06 \mathrm{~mm}$; $\mathrm{n}=18)$; transverse apertural diameter $0.03-0.07 \mathrm{~mm}$ (mean $=0.05 \mathrm{~mm} ; \mathrm{n}=18)$.

Description. - Encrusting, uniserial colonies with bifurcation every other autozooid (Fig. 3A-C). Bifurcation angles initially range from $130^{\circ}$ (Fig. 3A) to $180^{\circ}$ (Fig. 3B, C); subsequent angles are less than $90^{\circ}$. No complete ancestrula was found; the best-preserved example is broken and was at least $0.10 \mathrm{~mm}$ long (Fig. 3C). Autozooids with irregular shape depending on substrate; most slightly expand in width distally. Peristomes not preserved except for an occasional base (Fig. 3D). Pseudopores on the autozooids are circular and with somewhat irregular spacing.

Discussion. - This is the most common bryozoan in the Matmor fauna, yet we leave it in open nomenclature. Hara \& Taylor (1996, 2009) emphasized the value of zooid frontal wall widths in taxonomic assessment, and this technique is especially useful with species of Stomatopora. The Matmor Stomatopora species is significantly smaller than the other described species in zooid length, but the range of zooid distal width falls within the measurements of $S$. cf. dichotomoides described by Zatoń et al. (2013). Without a complete ancestrula, and early astogeny, we cannot definitively place the Matmor specimens in this species. For a partial synonymy of S. dichotomoides, see Hara \& Taylor (2009).

Occurrence. - C/W-172, C/W-173, C/W-247, C/W-366, C/W-600, C/W-602, C/W-608, C/W-609 (Table 1).

Family Oncousoeciidae Canu, 1918

\section{Genus Oncousoecia Canu, 1918}

Type species. - Tubulipora lobulata Canu, 1918; Recent, British Isles; see Taylor \& Zatoń (2008).

\section{Oncousoecia sp.}

Figure 4A-D

Material. - Three colonies encrusting a pluricolumnal of Apiocrinites negevensis (NHMUK BZ 7723, NHMUK BZ 7724).

Measurements. - Autozooid frontal wall width 0.08 to $0.13 \mathrm{~mm}($ mean $=0.10 \mathrm{~mm} ; \mathrm{n}=23)$; frontal wall length $0.28-0.31 \mathrm{~mm}($ mean $=0.29 \mathrm{~mm} ; \mathrm{n}=5)$; longitudinal aperture diameter $0.05-0.10 \mathrm{~mm}($ mean $=0.07 \mathrm{~mm} ; \mathrm{n}=21)$; 

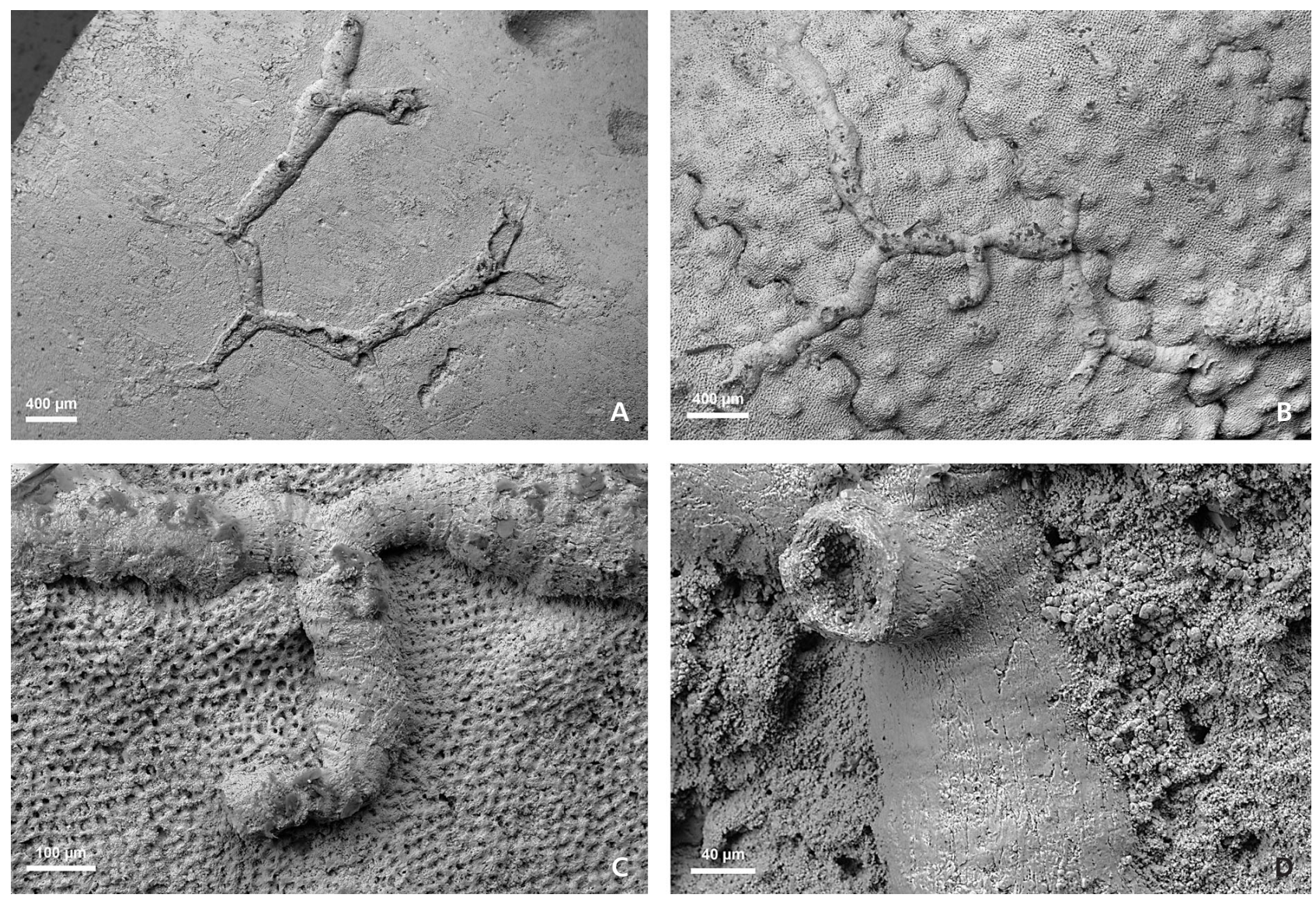

Figure 3. Stomatopora aff. dichotomoides (d'Orbigny, 1850) encrusting crinoid ossicles from the Matmor Formation (Callovian) of Hamakhtesh Hagadol, southern Israel. • A - partial colony showing abraded early zooids and initial branching angle, NHMUK BZ 7720; B - early portion of colony showing broken ancestrula, NHMUK BZ 7721; C - closer view of B with broken ancestrula and early autozooids; D - single autozooid with partial peristome, NHMUK BZ 7722.

transverse aperture diameter 0.04-0.07 (mean $=0.05 \mathrm{~mm}$; $\mathrm{n}=21$ ). Proximal portion of corroded gonozooid is approximately $0.30 \mathrm{~mm}$ long; ovoidal brood chamber is approximately $0.40 \mathrm{~mm}$ wide and $0.20 \mathrm{~mm}$ long.

Description. - Known from three eroded colonies in the Matmor Formation (Fig. 4A-C). Colonies encrusting, multiserial, expanding from one autozooid wide to at least 14 . Autozooids elongate, with circular pseudopores. One corroded gonozooid has a long, narrow proximal portion and a small, transversely ovoidal brood chamber (Fig. 4D). Another corroded gonozooid has a broken and unroofed brooding chamber.

Discussion. - With only three colonies found, this is the least common bryozoan species in the Matmor Formation. We have left it in open nomenclature because the gonozooids are too eroded for full characterization. Nevertheless, we can say that the Matmor Oncousoecia is not the same as Oncousoecia sp. 1 of Zaton et al. (2013) from the Middle Jurassic of Poland because its frontal wall widths are signifi- cantly smaller ( 0.10 vs $0.30 \mathrm{~mm})$. Oncousoecia $\mathrm{sp} .2$ of Zatoń et al. (2013, p. 842) also has wider frontal walls and a "longitudinally ovate" gonozooid contrasting with the transversely ovoidal gonozooid of the Matmor Oncousoecia. The Middle Jurassic Oncousoecia from Balin, Poland, described by Taylor (2009) has considerably larger autozooids (0.33-0.40 mm wide) and longitudinally elliptical pseudopores compared to the circular pseudopores of this species. Gonozooids are unknown in ?Oncousoecia sp. 1 and ?O. sp. 2 of Taylor \& Wilson (1999) from the Middle Jurassic of Utah, USA, but the autozooid frontal wall widths ( 0.75 to $1.38 \mathrm{~mm}$ and $0.19-0.26 \mathrm{~mm}$, respectively) in these species are significantly larger than the Matmor specimens.

Occurrence. - C/W-608 (Table 1).

\section{Genus Microeciella Taylor \& Sequeiros, 1982}

Type species. - Microeciella beliensis Taylor \& Sequeiros, 1982; Jurassic (Toarcian) of Belchite, Spain. 

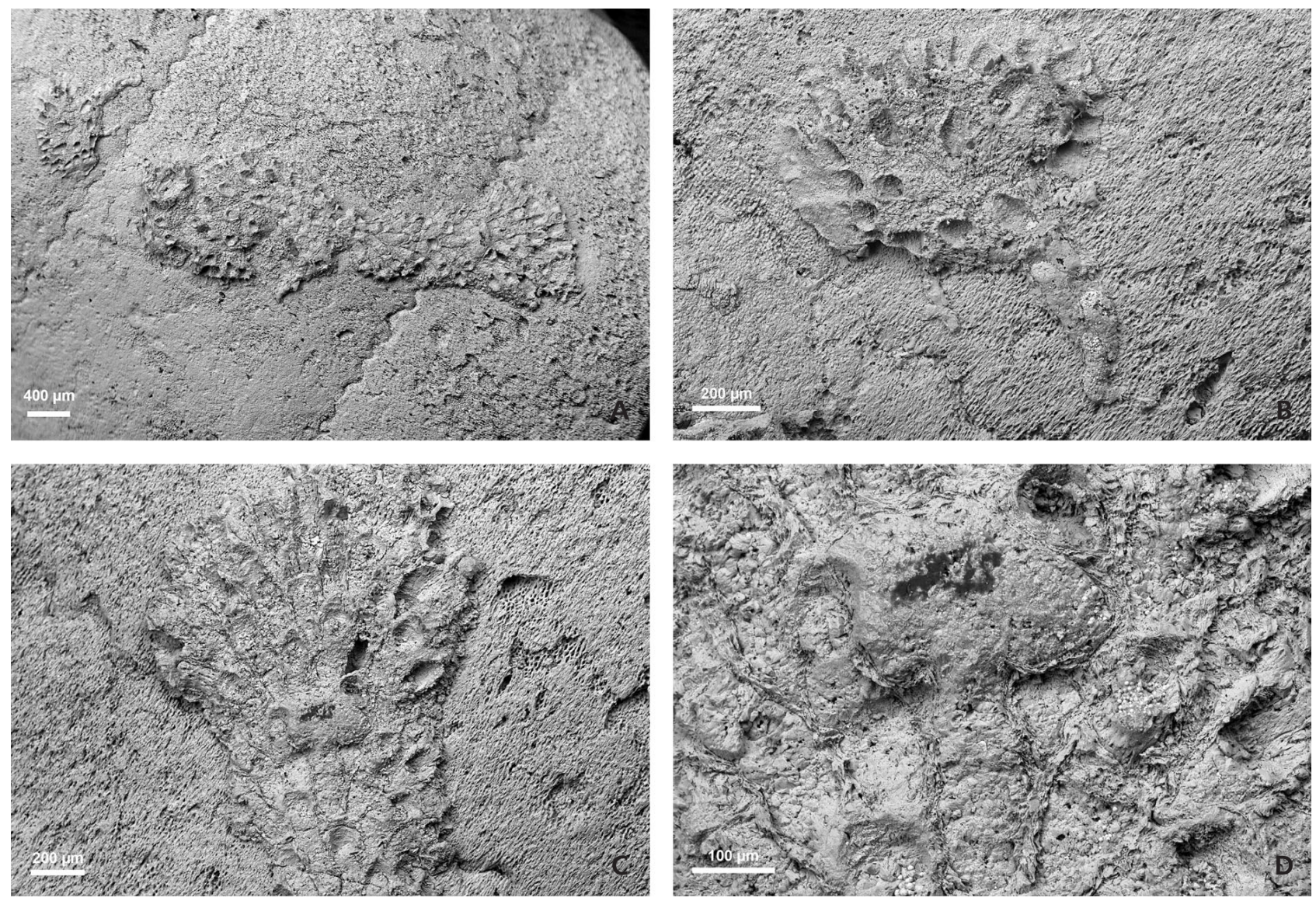

Figure 4. Oncousoecia sp. encrusting a crinoid pluricolumnal from the Matmor Formation (Callovian) of Hamakhtesh Hagadol, southern Israel, NHM UK BZ 7723. - A - two colonies; B - smaller of the colonies in Fig. 4A with abraded ancestrula; C - larger of the colonies in Fig. 4A; D - corroded gonozooid of the larger of the colonies in Fig. 4A.

\section{Microeciella yoavi sp. nov.} Figure 5A,B

Types. - Holotype: NHMUK BZ 7725 (Fig. 5A, B).

Type locality. - C/W-602; Matmor Formation (Middle Jurassic, Callovian, upper Peltoceras athleta Zone) in the Matmor Hills near the centre of Hamakhtesh Hagadol in southern Israel (Table 1).

Type horizon. - Subunit 51 (see Goldberg 1963) of the Matmor Formation, approximately 28 metres above the base of the unit.

Etymology. - Species named for Yoav Avni, a geologist with the Geological Survey of Israel who has organized palaeontological fieldwork in southern Israel and assisted with discovery and collection.

Material. - One colony with a gonozooid imaged and measured (NHMUK BZ 7725); numerous eroded colonies in collection.
Measurements. - Autozooid frontal wall width 0.07 to $0.10 \mathrm{~mm}$ (mean $=0.08 \mathrm{~mm} ; \mathrm{n}=12)$; frontal wall length 0.24 to $0.27 \mathrm{~mm}$ (mean $=0.26 \mathrm{~mm} ; \mathrm{n}=5)$; longitudinal aperture diameter $0.04-0.05 \mathrm{~mm}($ mean $=0.05 \mathrm{~mm} ; \mathrm{n}=6)$; transverse aperture diameter $0.03-0.05$ (mean $=0.04 \mathrm{~mm}$; $\mathrm{n}=6$ ). Holotype gonozooid proximal portion $0.27 \mathrm{~mm}$ long, $0.09 \mathrm{~mm}$ wide; distal brood chamber $0.30 \mathrm{~mm}$ long, $0.38 \mathrm{~mm}$ wide; total gonozooid length $0.58 \mathrm{~mm}$; ooeciopore diameter $0.05 \mathrm{~mm}$.

Description. - Colony encrusting, sheet-like, discoidal (Fig. 5C), multiserial, unilamellar. Autozooids small, elongate with convex frontal walls crossed by prominent growth bands; apertures small, circular to ovoidal; peristomes either short or abraded away (Fig. 5C); pseudopores subcircular and regularly spaced (Fig. 5D). Gonozooid distinctive, with a long proximal portion and a spherical brood chamber (Fig. 5C); dense array of circular pseudopores on brood chamber; ooeciopore terminal and about the same diameter as the autozooid apertures, strongly transversely elongate.

Discussion. - Microeciella yoavi sp. nov. may be relatively 

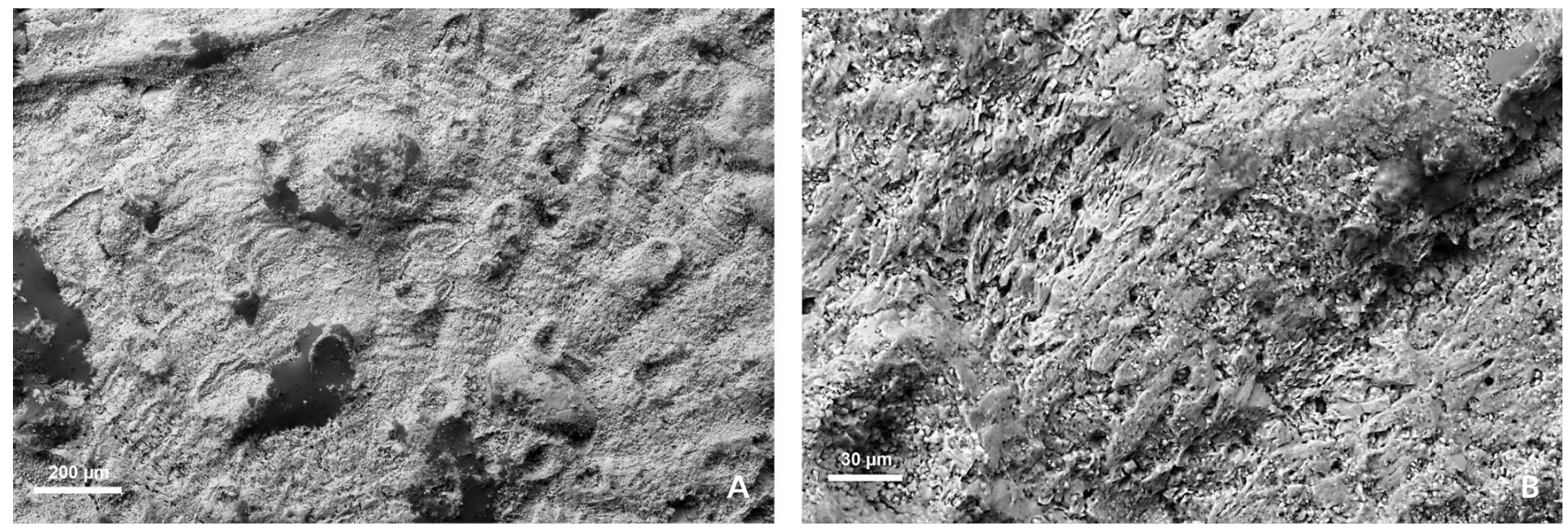

Figure 5. Microeciella yoavi sp. nov. encrusting crinoid ossicles from the Matmor Formation (Callovian) of Hamakhtesh Hagadol, southern Israel. - A - part of a circular colony with complete gonozooid, NHMUK BZ 7725 (a); B - closer view of colony in Fig. 5A showing pseudopores on autozooid frontal walls, NHMUK BZ 7725 (a).

common in the Matmor bryozoan fauna, but we have only one with a preserved gonozooid that enables secure identification. This species resembles $M$. cf. matisconensis and M. calloviana described in Zaton et al. (2013) from the Middle Jurassic of Poland. M. yoavi sp. nov., however, has significantly smaller autozooids (frontal wall width $0.07-0.12 \mathrm{~mm}$ compared to $0.10-0.17$ and $0.14-0.16 \mathrm{~mm}$, respectively) and a tiny, more spherical brood chamber.

Occurrence. - C/W-602 and C/W-608 (Table 1).

Family Multisparsidae Bassler, 1935

\section{Genus Idmonea Lamouroux, 1821}

Type species. - Idmonea triquetra Lamouroux, 1821; Bathonian of Calvados, France.

\section{Idmonea snehi sp. nov.}

Figure 6A-D

Types. - Holotype: NHMUK BZ 7726 (Fig. 5A-D); paratype: NHMUK BZ 7725(b).

Type locality. - C/W-247; Matmor Formation (Middle Jurassic, Callovian, upper Peltoceras athleta Zone) in the Matmor Hills near the centre of Hamakhtesh Hagadol in southern Israel. (See Table 1 for localities in subunit 51 of Goldberg 1963.)

Type horizon. - Subunit 51 (see Goldberg 1963) of the Matmor Formation, approximately 25 metres above the base of the unit.

Etymology. - Species named for Amihai Sneh, a geologist with the Geological Survey of Israel who first encouraged this work.

Material. - Two colonies (NHMUK BZ 7726, 7725(b)).

Measurements. - All measurements from holotype. Width of branches $0.21-0.63 \mathrm{~mm}$ ( mean $=0.42 \mathrm{~mm} ; \mathrm{n}=10)$; lateral budding angle of branches $76^{\circ}-124^{\circ}$ (mean $=97^{\circ}$; $\mathrm{n}=4)$. Autozooid frontal wall width $0.07-0.17 \mathrm{~mm}$ (mean $=0.11 \mathrm{~mm} ; \mathrm{n}=30)$; frontal wall length 0.22 to $0.33 \mathrm{~mm}($ mean $=0.26 \mathrm{~mm} ; \mathrm{n}=21)$; longitudinal aperture diameter $0.03-0.10 \mathrm{~mm}($ mean $=0.07 \mathrm{~mm} ; \mathrm{n}=25)$; transverse aperture diameter $0.03-0.09 \mathrm{~mm}($ mean $=0.06 \mathrm{~mm}$; $\mathrm{n}=26$ ).

Description. - Colony encrusting, with ribbon-like branches up to five autozooids wide, low and rounded in profile (Fig. 6A-C); lateral branches bud haphazardly at $76^{\circ}-124^{\circ}$ from the flanks of a parent branch, emerging from the aperture of an autozooid (Fig. 6A); terminal branch bifurcation not observed. Autozooids elongate but with indistinct zooidal boundaries; apertures circular or slightly transversely elongate, some with terminal diaphragms; peristomes either short or abraded (Fig. 6A-C). Kenozooids form a wide selvedge along the branch margins, distally diverging from the axis and tapering in height (Fig. 6B). Pseudopores circular, dense and well preserved across the autozooid frontal walls; less dense on kenozooids. Gonozooids not observed.

Discussion. - Mean autozooid size from the Matmor specimens fits well within the size range of the Idmonea sp. described from the Maastrichtian (Upper Cretaceous) by Di Martino \& Taylor (2013). It is also within the size range of an undescribed species of Idmonea from the Bathonian-Callovian of Balin, Poland (Taylor 2009). However, 

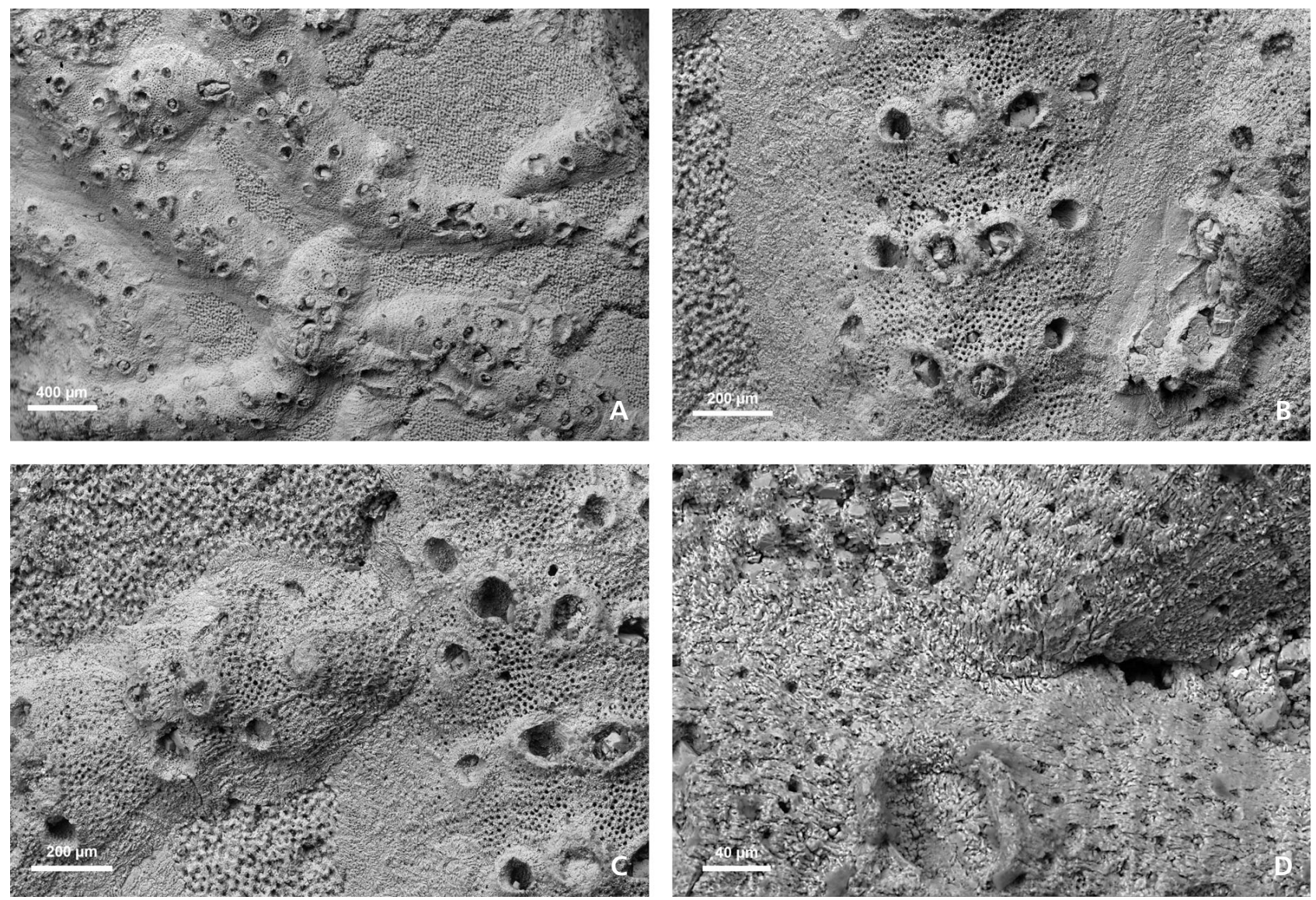

Figure 6. Idmonea snehi sp. nov. encrusting a crinoid pluricolumnal from the Matmor Formation (Callovian) of Hamakhtesh Hagadol, southern Israel, NHMUK BZ 7726. • A - colony showing lateral branching pattern; B - branch with selvedge made of kenozooids; C - budding point of lateral branch; $\mathrm{D}$ - closer view of budding point showing shapes of pseudopores.

the presence of lateral branching, which is profuse in I. snehi, distinguishes the new species from all Jurassic species of Idmonea. Indeed, the customary terminal branching seen in Idmonea seems to be lacking in the new species, to be replaced entirely by lateral branching. The lateral branching pattern of Idmonea snehi is the earliest example of lateral branching in a post-Palaeozoic cyclostome, and the only published example of lateral branching in any Jurassic bryozoan. Worn lateral branch origins show the branches emerge from an aperture in the outermost row of autozooids.

Occurrence. - C/W-247 and C/W-602 (Table 1).

Family Plagioeciidae Canu, 1918

\section{Genus Hyporosopora Canu \& Bassler, 1929}

Type species. - Hyporosopora typica Canu \& Bassler, 1929; Bathonian of Calvados, France.

\section{Hyporosopora nana sp. nov.}

Figure 7A-D

Types. - Holotype: NHMUK BZ 7727(c) (Fig. 7A, B, D). Paratypes (on the same substrate as holotype): NHMUK BZ 7727(a), BZ 7727(b) (Fig. 7C).

Type locality. - C/W-371; Matmor Formation (Middle Jurassic, Callovian, upper Peltoceras athleta Zone) in the Matmor Hills near the centre of Hamakhtesh Hagadol in southern Israel (Table 1).

Type horizon. - Subunit 51 (see Goldberg 1963) of the Matmor Formation, approximately 28 metres above the base of the unit.

Etymology. - The Latin nana means small. It is used here in reference to the very small autozooids in this species.

Material. - Several specimens but only the holotype and one paratype are fertile with diagnostic gonozooids. 

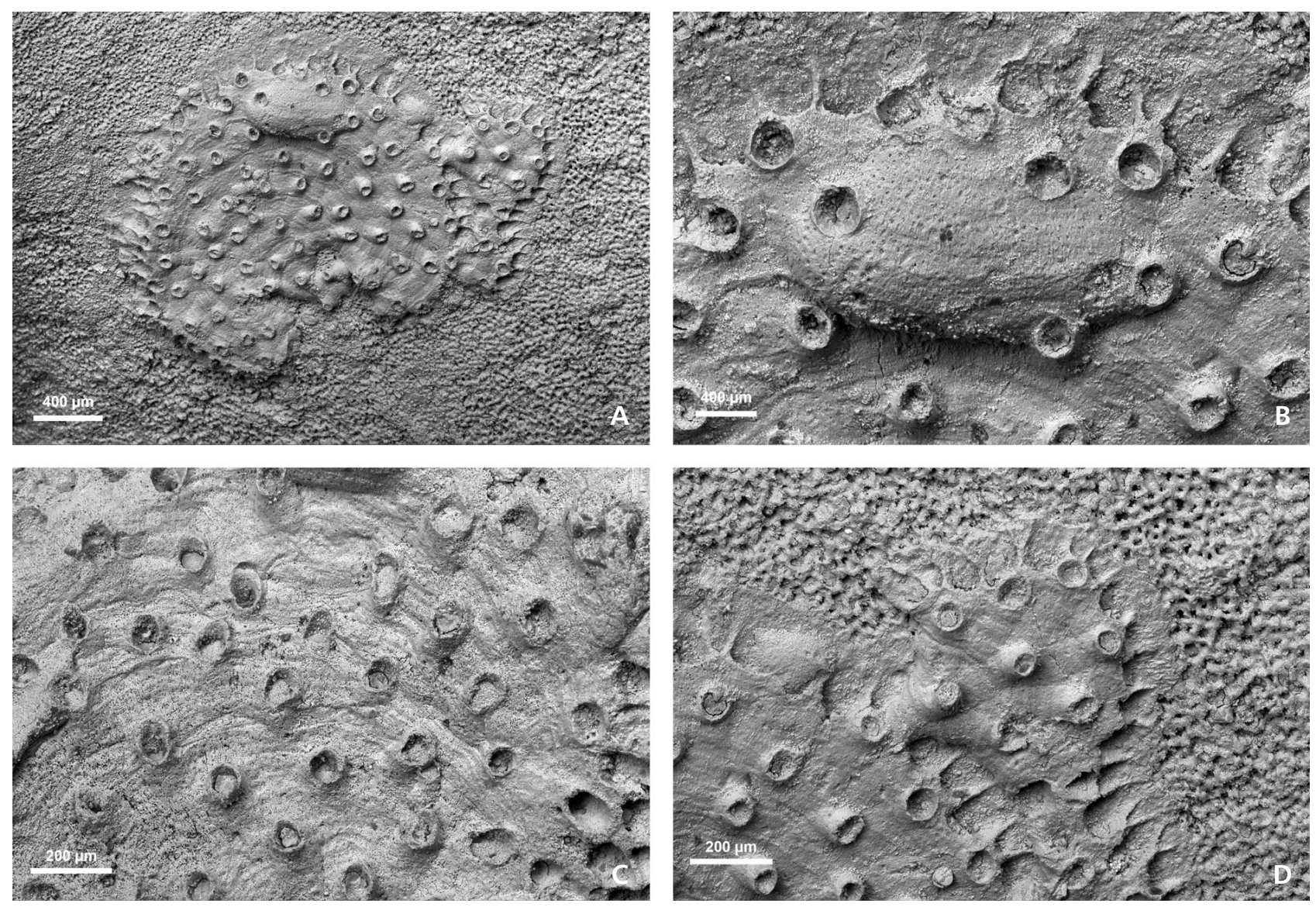

Figure 7. Hyporosopora nana sp. nov. encrusting a crinoid holdfast from the Matmor Formation (Callovian) of Hamakhtesh Hagadol, southern Israel. - A - complete colony showing ancestrula, gonozooid and subcolonies on the right, NHMUK BZ 7727(c); B - gonozooid with ooeciopore at the distal end, NHMUK BZ 7727(c); C - autozooid frontal walls with pseudopores, NHMUK BZ 7727(b); D - subcolony budding from periphery of main colony, NHMUK BZ 7727(c).

Measurements. - All measurements are from the holotype. Autozooid frontal wall width $0.05-0.07 \mathrm{~mm}$ (mean $=$ $0.06 \mathrm{~mm} ; \mathrm{n}=8$ ); frontal wall length $0.20-0.30 \mathrm{~mm}$ (mean = $0.24 \mathrm{~mm} ; \mathrm{n}=11)$; longitudinal aperture diameter 0.02 to $0.05 \mathrm{~mm}($ mean $=0.03 \mathrm{~mm} ; \mathrm{n}=15)$; transverse aperture diameter $0.01-0.04$ (mean $=0.02 \mathrm{~mm} ; \mathrm{n}=15)$. Gonozooid length $0.02 \mathrm{~mm}$, width $0.31 \mathrm{~mm}$; ooeciopore longitudinal aperture diameter $0.02 \mathrm{~mm}$, latitudinal aperture diameter $0.02 \mathrm{~mm}$.

Description. - Colony encrusting, sheet-like, multiserial, unilamellar, ovoidal (Fig. 7A); subcolonies branching from distal growing edge of parent colony which is low and exposes one generation of buds (Fig. 7D). Autozooids small, with slightly convex frontal walls crossed by transverse growth lines; shallow indentations at zooidal boundaries; apertures small subcircular or longitudinally ovoidal; peristomes short or broken; terminal diaphragms often present; pseudopores circular (Fig. 7C, D). Gonozooid transversely ovoidal (Fig. 7B), margins indented by a few autozooidal apertures; ooeciopore diameter at small end of autozooid transverse aperture diameter range; pseudopores circular and dense across gonozooid surface (Fig. 7B). Ancestrula about $0.28 \mathrm{~mm}$ long, damaged in the single known example but with aperture estimated to be $0.05 \mathrm{~mm}$ in transverse diameter and protoecium $120 \mu \mathrm{m}$ wide.

Discussion. - Hyporosopora nana is similar to H. tenera (Reuss, 1867) as described by Taylor (2009) and Zatoń \& Taylor (2009) from the Middle Jurassic of Poland. H. nana and $H$. tenera both have elliptical gonozooids, as well as the same general colony shape. H. nana, however, has considerably smaller autozooidal frontal wall widths of 0.05 to $0.07 \mathrm{~mm}$, compared to $0.11-0.14 \mathrm{~mm}$ in $H$. tenera (see also Zatoń et al. 2013). Zatoń \& Taylor (2009) reported an ooeciopore length of $0.066 \mathrm{~mm}$ and width of $0.091 \mathrm{~mm}$ for $H$. tenera, whereas $H$. nana has a significantly smaller ooeciopore length of $0.02 \mathrm{~mm}$ and width of $0.02 \mathrm{~mm}$. The same pattern holds true for all other measurements as well. H. nana has the smallest zooids in the Matmor Hyporosopora assemblage, as well the smallest so far identified in the literature for the genus. 

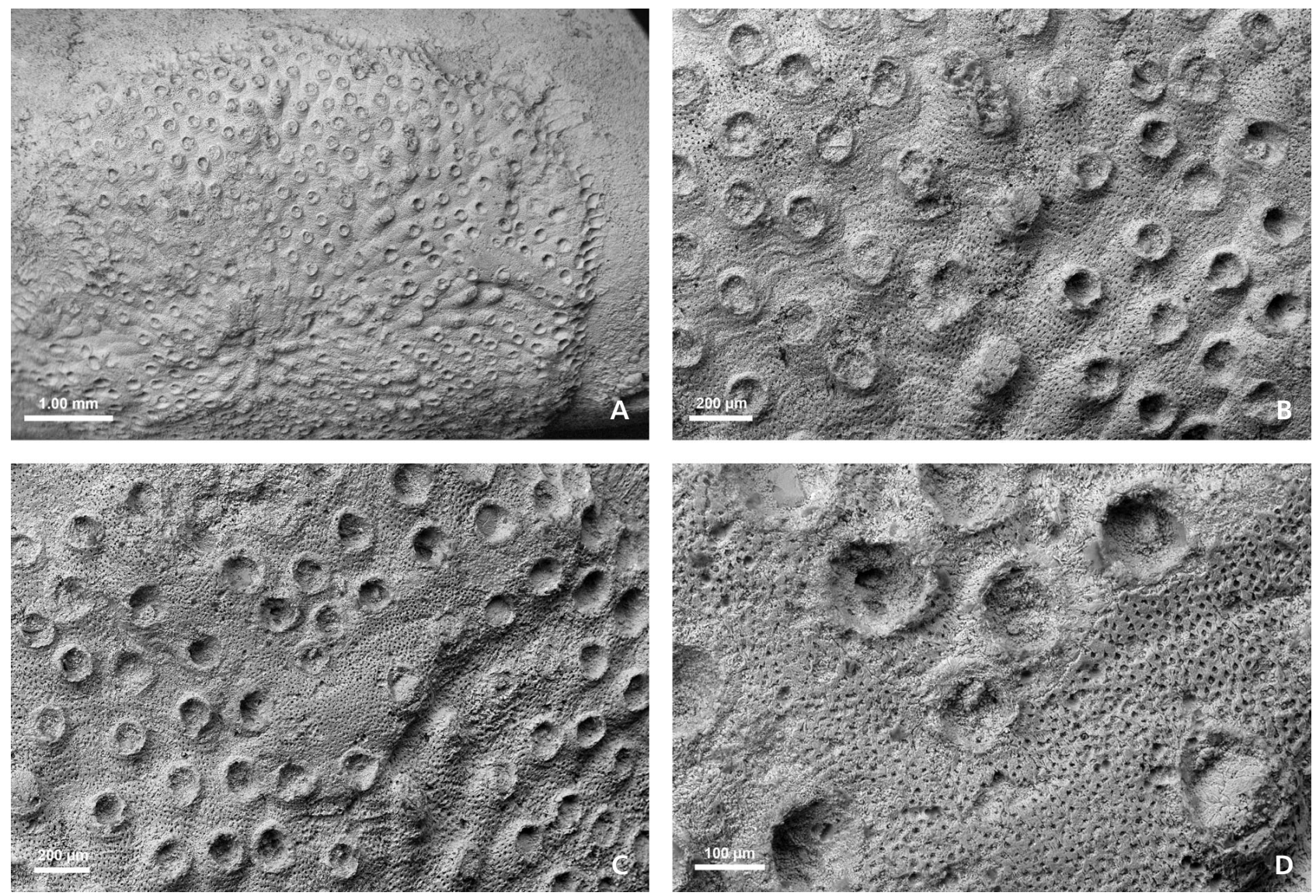

Figure 8. Hyporosopora negevensis sp. nov. encrusting a crinoid pluricolumnal from the Matmor Formation (Callovian) of Hamakhtesh Hagadol, southern Israel, NHMUK BZ 7728. • A - complete colony showing gonozooid; B - autozooids with pseudopores; C - boomerang-shaped gonozooid with ooeciopore at the junction of the two arms; D - closer view of ooeciopore and pseudopores in Fig. 8C.

Occurrence. - C/W-371 and C/W-602 (Table 1).

\section{Hyporosopora negevensis sp. nov.} Figure 8A-D

Types. - Holotype: NHMUK BZ 7728 (Fig. 8).

Type locality. - C/W-609; Matmor Formation (Middle Jurassic, Callovian, upper Peltoceras athleta Zone) in the Matmor Hills near the centre of Hamakhtesh Hagadol in southern Israel (Table 1).

Type horizon. - Subunit 51 (see Goldberg 1963) of the Matmor Formation, approximately 28 metres above the base of the unit.

Etymology. - The species name negevensis refers to the type locality in the Negev Desert.

Material. - Several specimens but only the holotype is fertile (NHMUK BZ 7728).
Measurements. - All measurements are from the holotype. Autozooid frontal wall width 0.10 to $0.16 \mathrm{~mm}$ (mean = $0.13 \mathrm{~mm} ; \mathrm{n}=20$ ); frontal wall length $0.33-0.44 \mathrm{~mm}$ (mean $=0.36 \mathrm{~mm} ; \mathrm{n}=12)$; longitudinal aperture diameter $0.06-0.10 \mathrm{~mm}($ mean $=0.09 \mathrm{~mm} ; \mathrm{n}=30)$; transverse aperture diameter $0.05-0.10$ (mean $=0.08 \mathrm{~mm} ; \mathrm{n}=35)$. Brood chamber length of median axis (to the ooeciopore) is $0.60 \mathrm{~mm}$; distal width of brood chamber is $1.87 \mathrm{~mm}$; ooeciopore longitudinal aperture diameter $0.07 \mathrm{~mm}$, latitudinal aperture diameter $0.05 \mathrm{~mm}$.

Description. - Colony encrusting, sheet-like, multiserial, unilamellar, ovoidal. Growing edge shallow, usually revealing only one generation of buds. Autozooids moderately large, with slightly convex frontal walls crossed locally by transverse growth lines; boundary walls marked by slight grooves; apertures crowded, longitudinally ovoidal, some closed by terminal diaphragms; peristomes short or abraded; pseudopores teardrop-shaped. Gonozooid boomerang-shaped with ooeciopore at base of the two lateral lobes; ooeciopore circular, slightly smaller than an autozooidal aperture; pseudopores dense. 
Discussion. - Hyporosopora negevensis is similar to $H$. radomensis described by Hara \& Taylor (2009) from the Polish Kimmeridgian; both have boomerang-shaped gonozooids; however, the measurements of the gonozooid length and width, as well as the size of the ooeciopore, differ. The frontal wall widths of $H$. radomensis autozooids are reported as $0.105-0.180 \mathrm{~mm}$. The frontal wall widths of $H$. negevensis are 0.098-0.163 mm, which is smaller than $H$. radomensis, though with some overlap. The frontal wall lengths are appreciably different: $0.520-0.840 \mathrm{~mm}$ in $H$. radomensis vs $0.331-0.435 \mathrm{~mm}$ in $H$. negevensis. The pseudopores on the autozooids of the Matmor species are much more densely packed than on $H$. radomensis (Hara \& Taylor, 2009, p. 572, fig. 10c), and they are circular rather than drop-shaped or crescent-shaped as in H. sauvagei.

Occurrence. - C/W-609 (Table 1).

\section{Discussion and conclusions}

The tropical Matmor bryozoan fauna resembles other Middle Jurassic assemblages in that it has the three encrusting colony-forms typical of Jurassic bryofaunas: uniserial branching runners (here as Stomatopora), oligoserial branching ribbons (Oncousoecia and Idmonea) and multiserial sheets (Hyporosopora and Microeciella). In this sense the fauna is very similar at generic level to those from the temperate Middle Jurassic of Europe, e.g., Poland (Taylor 2009, Zatoń \& Taylor 2010, Zatoń et al. 2013). However, at the species level the Matmor bryozoans are distinct: of the six species described here, four are new.

The diversity and abundance of the Matmor bryozoan fauna warrant discussion. Despite over a decade of intense collecting, only the six species described here have been found, and most within a single marl-rich unit in the formation. Taylor \& Ernst (2008) noted that the Middle Jurassic was a time when bryozoan diversity was only just beginning to recover from the long-lasting effects of the end-Permian, and possibly the late Triassic, extinction events. Bryozoan assemblages from the Middle Jurassic are the most diverse of the period, with an average species richness of 5.2 and a median of 17 per assemblage. The Matmor bryozoan assemblage matches Taylor \& Ernst's (2008) average, but it falls well short of the median of 17 species. The bryozoan assemblages in Poland easily meet and many exceed the Middle Jurassic average and median (Taylor 2009, Zatoń \& Taylor 2009, Zatoń et al. 2013). The Bathonian bryozoan assemblage in the Carmel Formation of southern Utah, USA, contains only seven cyclostome species and thus has a similar species richness, but the abundance of bryozoans there is far greater (Taylor \& Wilson 1999). The Carmel fauna was also more environmentally restricted as indicated by an almost total lack of brachiopods (there are only a few thecideides) and echinoderms.

Our hypothesis is that the Matmor bryozoans were less diverse and abundant than their temperate equivalents because they lived in an oligotrophic, tropical environment (as supported by the abundance of corals in the Matmor Formation; see Hallock et al. 1988, and references therein). Taylor \& Allison (1998) showed that bryozoans are insignificant contributors of sediment in the post-Palaeozoic tropics, reflecting their small biomass. This contrasts with their significant contribution to Palaeozoic tropical sediments. There are far too few data points to discuss a Jurassic latitudinal trend for bryozoan diversity, but it is worth noting that the Matmor fauna in the Middle East was on the southwestern flank of the Tethys Ocean almost directly south of Europe with no land barriers between the living communities. Zatoń et al. (2013) described 22 cyclostome species from a single Callovian locality in Poland, which is almost four times more than the diversity of the Callovian cyclostomes in this Israeli fauna.

All of the Matmor bryozoan genera are known from earlier and later Jurassic occurrences, so this tropical fauna does not seem to represent either a "cradle" or "a museum of biodiversity" for the cyclostomes (Jablonski et al. 2006, p. 102). However, Idmonea snehi in this assemblage is the first occurrence of lateral branching among cyclostome bryozoans, and thus far the only Jurassic example. Most encrusting cyclostomes exhibit terminal branching whereby bifurcation at distal growing tips causes branch multiplication. In contrast, lateral branches originate from the sides of existing branches, proximal of the growing tips. This process requires either skeletal resorption, as proposed by Harmelin (1976), or the retention of an uncalcified patch behind the advancing growing tip from which budding to produce a lateral branch can later be activated. The latter appears to be the case in I. snehi where the lateral branches seem to emerge from autozooidal apertures. The oldest example of lateral branching in a cyclostome is recorded in Cuffyella arachnoidea (Hall, 1847), a palaeotubuliporine common in the Cincinnatian (Late Ordovician) of the US mid-west (Taylor \& Wilson 1996). Until the discovery of $I$. snehi from the Callovian, this style of branching was thought not to reappear in cyclostomes until the Early Cretaceous (Hauterivian) from where Jablonski et al. (1997, p. 519) recorded its occurrence in an un-named species of the uniserial tubuliporine Voigtopora.

Jurassic encrusting bryozoans are most commonly found in cryptic spaces such as the undersides of corals and sponges or the interiors of bivalves (Taylor \& Ernst 2008). Previous observations of the Matmor bryozoans (Wilson $e t$ al. 2008, 2010) suggested that they too were mostly cryptic, but the thorough survey in this work shows that instead the majority lived on exposed surfaces. Out of the $130 \mathrm{col}-$ onies examined, all but a few encrusted upward-facing sur- 
faces of echinoderm ossicles that were sitting on top of marl-rich sediments. There are numerous corals and sponges in this same unit with cryptic undersurfaces encrusted by serpulids, sabellids and thecideide brachiopods, but bryozoans are nearly absent there (Wilson et al. 2008, Vinn \& Wilson 2010). This is a very Palaeozoic-like microenvironmental distribution similar to the bryozoans that encrusted exposed crinoid calyxes and stems in the Silurian Waldron Shale of Indiana, USA (Liddell \& Brett 1982).

The Matmor bryozoans, especially Hyporosopora, have significantly smaller zooids than their temperate equivalents in Europe (see Systematics section above). This appears to be an example of the "temperature-size rule" where temperature and size have an inverse relationship as shown by many ectotherms (Atkinson 1994). The relationship has been studied extensively in a laboratory setting among conspecific colonies of modern cheilostome bryozoans: "Temperature consistently provides, either directly or indirectly, a pervading and dominant influence on zooid size" (Okamura et al. 2011, p. 144). While most data concerns temperature-related differences in zooid size within cheilostome species, or even within colonies, there are indications that the relationship may also operate between species of the same genus (Kukliński \& Taylor 2008) and among stenolaemates too (Jiménez-Sánchez et al. 2013). Therefore the small zooid sizes of the Matmor cyclostome species may be a function of their development on a warm, tropical shelf. This is in contrast to the larger zooids typifying congeneric bryozoan species growing in the cooler, temperate waters of Europe (Taylor \& Wilson 1999, Hara \& Taylor 2009, Zatoń et al. 2013).

\section{Acknowledgments}

We thank several College of Wooster students who collected bryozoan specimens (whether they knew it or not) from the Matmor Formation over the years: J. Bowen, S. Lehmann, M. Sharpe, M. Torma, E. Krivicich, W. Cary, E. Reinthal, and O. Mmari. We are also grateful to support and advice from Y. Avni and A. Sneh of the Geological Survey of Israel. U. Hara and M. Zaton provided very helpful reviews of this manuscript. This work was supported by the Wengerd, Luce and Faculty Development Funds at The College of Wooster. We also thank the Donors of the Petroleum Research Fund, administered by the American Chemical Society, for partial support of this research.

\section{References}

Aberhan, M., Kiessling, W. \& Fürsich, F.T. 2006. Testing the role of biological interactions in the evolution of mid-Mesozoic marine benthic ecosystems. Paleobiology 32, 259-277. DOI $10.1666 / 05028.1$
AtKinson, D. 1994. Temperature and organism size: a biological law for ectotherms? American Naturalist 162, 332-342.

Ausich, W.I. \& WiLson, M.A. 2012. New Tethyan Apiocrinitidae (Crinoidea, Articulata) from the Jurassic of Israel. Journal of Paleontology 86, 1051-1055. DOI 10.1666/12-049R.1

AvnI, Y. 2001. Structure and landscape evolution of the Makhteshim country - interrelations between monoclines, truncation surfaces and the evolution of the Makhteshim, 33-58. In Krasnov, B. \& Mazor, E. (eds) Makhteshim Country: A Laboratory of Nature: Geological and Ecological Studies in the Desert Region of Israel. Pensoft Publishers, Sofia.

BASSLER, R.S. 1935. Bryozoa. Generum et Genotyporum. Index et Bibliographica, 1-229. In Quenstedt, W. (ed.) Fossilium Catalogus I. Animalia. Vol. Part 67. W. Junk, s'Gravenhage.

BronN, H.G. 1825. System der urweltlichten Pflanzenthiere durch Diagnose, Analyse und Abbildung der Geschlechter erläutert. $47 \mathrm{pp}$. Mohr, Heidelberg.

Busk, G. 1852. An account of the Polyzoa and Sertularian Zoophytes collected in the voyage of the Rattlesnake on the coast of Australia and the Louisiade Archipelago, 343-402. In MacGillivray, J. (ed.) Narrative of the Voyage of H.M.S. Rattlesnake, commanded by the late Captain Owen Stanley, during the years 1846-1850, 1. Boone, London.

CAnu, F. 1918. Les ovicelles des Bryozoaires cyclostomes. Études sur quelques familles nouvelles et anciennes. Bulletin de la Société géologique de France 4, 324-335.

CAnu, F. \& Bassler, R.S. 1929. Etudes sur les ovicelles des Bryozoaires jurassiques. Bulletin de la Société Linnéenne de Normandie 8, 113-131.

Cariou, E.J.P., Bassoullet, L., Grossowicz, L. \& Hirsch, F. 1997. Le Callovo-Oxfordien du Sud Levant: données biostratigraphiques nouvelle (ammonites, foraminifères) endémesme et corréations stratigraphiques, 21. In SociÉTÉ GÉOlogique de France (ed.) Réunion Spécialisée APF-SGF "De la Biostratigraphie à la Paléobiogéographie", Lyon, 21-28 novembre 1997.

Cuffey, R.J. \& Ehleiter, J.E. 1984. New bryozoan species from the Mid-Jurassic Twin Creek and Carmel Formations of Wyoming and Utah. Journal of Paleontology 58, 668-682.

Di Martino, E. \& TAYlor, P.D. 2013. First bryozoan fauna from a tropical Cretaceous carbonate: Simsima Formation, United Arab Emirates-Oman border region. Cretaceous Research 43, 80-96. DOI 10.1016/j.cretres.2013.02.004

Feldman, H.R. \& Brett, C.E. 1998. Epi- and endobiontic organisms on Late Jurassic crinoid columns from the Negev Desert, Israel: Implications for co-evolution. Lethaia 31, 57-71. DOI 10.1111/j.1502-3931.1998.tb00491.x

Feldman, H.R., Owen, E.F. \& HiRsch, F. 2001. Brachiopods from the Jurassic (Callovian) of Hamakhtesh Hagadol (Kurnub Anticline), southern Israel. Palaeontology 44, 637-658. DOI 10.1111/1475-4983.00195

Feldman, H.R., Schemm-Gregory, M., Ahmad, F. \& Wilson, M.A. 2012. Jurassic rhynchonellide brachiopods from the Jordan Valley. Acta Palaeontologica Polonica 57, 191-204. DOI 10.4202/app.2010.0092

Gill, G.A., Thierry, J. \& TinAnt, H. 1985. Ammonites calloviennes du Sud d'Israël: Systématique, biostratigraphie et paléobiogéographie. Geobios 18(6), 705-767. DOI 10.1016/S0016-6995(85)80033-4

Gill, G.A. \& Tintant, H. 1975. Les ammonites calloviennes du Sud d'Israël. Israel Journal of Earth Sciences 14, 122-138. 
GoldBERG, M. 1963. Reference section of Jurassic sequence in Hamakhtesh Hagadol (Kurnub Anticline). Detailed binocular sample description, including field observations. $50 \mathrm{pp}$. Unpublished report, Israel Geological Survey.

GolonKA, J. 2004. Plate tectonic evolution of the southern margin of Eurasia in the Mesozoic and Cenozoic. Tectonophysics 381, 35-273. DOI 10.1016/j.tecto.2002.06.004

Grossowicz, L.P., Bassoullet, J.-P., Hirsch, F. \& Peri, M. 2000. Jurassic large Foraminifera from Israel. Geological Survey of Israel, Current Research 12, 132-144.

Hall, J. 1847. Organic remains of the lower division of the New-York system. Natural History of New York, Part 6, Palaeontology of New York 1, 1-338.

Hallock, P., Hine, A.C., Vargo, G.A., Elrod, J.A. \& JaAP, W.C. 1988. Platforms of the Nicaraguan Rise: Examples of the sensitivity of carbonate sedimentation to excess trophic resources. Geology 16, 1104-1107.

DOI 10.1130/0091-7613(1988)016<1104:POTNRE >2.3.CO;2

HaQ, B.U. \& Al-QAhtani, A.M. 2005. Phanerozoic cycles of sea-level change on the Arabian Platform. GeoArabia 10, $127-160$.

HARA, U. \& TAYLOR, P.D. 1996. Jurassic bryozoans from Bałtów, Holy Cross Mountains, Poland. Bulletin of The Natural History Museum, London (Geology Series) 52, 91-102.

HaRA, U. \& TAYLOR, P.D. 2009. Cyclostome bryozoans from the Kimmeridgian (Upper Jurassic) of Poland. Geodiversitas 31, 555-575. DOI $10.5252 / \mathrm{g} 2009 \mathrm{n} 3 \mathrm{a} 4$

Harmelin, J.-G. 1976. Le sous-ordre des Tubuliporina (Bryozoaries Cyclostomes) en Méditerranée, écologie et systématique. Mémoires de l'Institut Océanographique, Monaco 10, $1-326$.

HiRsCH, F. 1979. Jurassic bivalves and gastropods from northern Sinai and southern Israel. Israel Journal of Earth Sciences 28, 128-163.

Hirsch, F., Bassoullet, J.-P., Cariou, E., Conway, B., Feldman, H.R., Grossowicz, L., Honigstein, A., Owen, E.F. \& Rosenfeld, A. 1998. The Jurassic of the southern Levant. Biostratigraphy, palaeogeography and cyclic events, 213-235. In Carasquin-Soleau, S. \& Barrier, É. (eds) Peri-Tethys Memoir 4: Epicratonic Basins of Peri-Tethyan Platforms. Mémoires du Muséum national d'histoire naturelle, Paris 179.

HIRSCH, F. \& RoDED, R. 1997. The Jurassic stratigraphic nomenclature in Hamakhtesh Hagadol, northern Negev. Geological Survey of Israel, Current Research 10, 10-14.

Hudson, R.G.S. 1958. The Upper Jurassic faunas of southern Israel. Geological Magazine 95, 415-425. DOI 10.1017/S0016756800062993

Jablonski, D., Roy, K. \& Valentine, J.W. 2006. Out of the tropics: evolutionary dynamics of the latitudinal diversity gradient. Science 314, 102-106. DOI 10.1126/science.1130880

JimÉnez-SÁnchez, A., TAYloR, P.D. \& Gómez, J.B. 2013. Palaeogeographical patterns in Late Ordovician bryozoan morphology as proxies for temperature. Bulletin of Geosciences 88(2), 417-426. DOI 10.3140/bull.geosci.1396

KrawCZyŃski, C. \& WiLSON, M.A. 2011. The first Jurassic thecideide brachiopods from the Middle East: A new species of Moorellina from the Upper Callovian of Hamakhtesh Hagadol, southern Israel. Acta Geologica Polonica 61, 71-77.

KuKLIŃSKI, P. \& TAYLOR, P.D. 2008. Are bryozoans adapted for living in the Arctic? Virginia Museum of Natural History, Special Publication 15, 101-110.

Lamouroux, J.V. 1821. Exposition méthodique des genres de l'ordre des polpiers. 115 pp. Agasse, Paris.

LEWY, Z. 1983. Upper Callovian ammonites and Middle Jurassic geological history of the Middle East. Israel Geological Survey Bulletin 76, 1-56.

LidDELL, D.W. \& BRETT, C.E. 1982. Skeletal overgrowths among epizoans from the Silurian (Wenlockian) Waldron Shale. Paleobiology 8, 67-78.

Newton, R.B. 1921. On a marine Jurassic fauna from Central Arabia. Annals and Magazine of Natural History 9(7), 389-403. DOI 10.1080/00222932108632538

Okamura, B., O'Dea, A. \& Knowles, T. 2011. Bryozoan growth and environmental reconstruction by zooid size variation. $M a$ rine Ecology Progress Series 430, 133-146. DOI $10.3354 / \mathrm{meps} 08965$

ORBIGNY, A. D' 1850. Prodrome de paléontologie stratigraphique universelle des animaux mollusques et rayonnés. Tome 1. 394 pp. Masson, Paris. DOI 10.5962/bhl.title.62810

Pandey, D.K., Ahmad, F. \& Fürsich, F.T. 2000. Middle Jurassic scleractinian corals from northwestern Jordan. Beringeria 27, 3-29.

Pergens, E. \& Meunier, A. 1886. La faune des Bryozoaires garumniens de Faxe. Annales de la Société Royale Malacologique de Belgique 12, 181-242.

ReINER, W. 1968. Callovian gastropods from Hamakhtesh Hagadol (southern Israel). Israel Journal of Earth Sciences 17, 171-198.

Reuss, A.E. 1867. Die Bryozoen, Anthozoen und Spongiaren des braunen Jura von Balin bei Krakau. Denkschriften der Kaiserlichen Akademie der Wissenschaften, Wien, Mathematisch-naturwissenschaftliche Klasse 27, 1-26.

Sharland, P.R., Casey, D.M., Davies, R.B., Simmons, M.D. \& SutclifFe, O.E. 2004. Arabian Plate sequence stratigraphy. GeoArabia 9, 199-214.

TAYLOR, P.D. 2009. Bryozoans from the Middle Jurassic of Balin, Poland: a revision of material described by A.E. Reuss (1867). Annalen des Naturhistorisches Museum in Wien 110 A, 17-54.

TAYLOR, P.D. \& Allison, P.A. 1998. Bryozoan carbonates in space and time. Geology 26, 459-462.

DOI 10.1130/0091-7613(1998)026<0459:BCTTAS >2.3.CO;2

TAYLOR, P.D. \& ERNST, A. 2008. Bryozoans in transition: the depauperate and patchy Jurassic biota. Palaeogeography, Palaeoclimatology, Palaeoecology 263, 9-23. DOI 10.1016/j.palaeo.2008.01.028

TAYloR, P.D. \& SEqueIros, L. 1982. Toarcian bryozoans from Belchite in north-east Spain. Bulletin of the British Museum (Natural History), Geology Series 37, 117-129.

TAYLOR, P.D. \& WiLson, M.A. 1996. Cuffeyella, a new bryozoan genus from the Late Ordovician of North America, and its bearing on the origin of the post-Paleozoic cyclostomes, 351-360. In Gordon, D.P., Smith, A.M. \& GRanT-Mackie, J.A. (eds) Bryozoans in Space and Time. NIWA, Wellington.

TAYLOR, P.D. \& WiLson, M.A. 1999. Middle Jurassic bryozoans from the Carmel Formation of southwestern Utah. Journal of Paleontology 73, 816-830.

TAYLOR, P.D. \& WILSON, M.A. 2002. A new terminology for marine organisms inhabiting hard substrates. Palaios 17, $522-525$.

DOI 10.1669/0883-1351(2002)017<0522:ANTFMO>2.0.CO;2 
TAYLOR, P.D. \& WILSON, M.A. 2003. Palaeoecology and evolution of marine hard substrate communities. Earth-Science Reviews 62,1-103. DOI 10.1016/S0012-8252(02)00131-9

TAYLOR, P.D. \& ZATON, M. 2008. Taxonomy of the bryozoan genera Oncousoecia, Microeciella and Eurystrotos (Cyclostomata: Oncousoeciidae). Journal of Natural History 42, 2557-2574.

VermeIJ, G.J. 1977. The Mesozoic marine revolution: Evidence from snails, predators and grazers. Paleobiology 3, 245-258.

VERMEIJ, G.J. 2008. Escalation and its role in Jurassic biotic history. Palaeogeography, Palaeoclimatology, Palaeoecology 263, 3-8. DOI 10.1016/j.palaeo.2008.01.023

VinN, O. \& WiLson, M. A. 2010. Sabellid-dominated shallow water calcareous polychaete tubeworm association from the equatorial Tethys Ocean (Matmor Formation, Middle Jurassic, Israel). Neues Jahrbuch für Geologie und Paläontologie 258, 31-38. DOI 10.1127/0077-7749/2010/0080

Viskova, L.V. 2006. Bryozoans of the genera Stomatopora Bronn and Stoporatoma gen. nov. (Stenolaemata) from the Middle Jurassic of Moscow City and the Moscow region. Paleontological Journal 40(4), 425-430. DOI 10.1134/S0031030106040071

ViskovA, L.V. 2007. New bryozoans (Stenolaemata) from the Middle Jurassic of Moscow City and the Moscow Region. Paleontological Journal 41(1), 49-60. DOI 10.1134/S0031030107010054

VisKovA, L.V. 2008. New stenolaematous bryozoans from the Jurassic of Central European Russia (Moscow City and the Moscow and Kostroma Regions). Paleontological Journal 42(2), 149-158. DOI 10.1007/s11492-008-2005-8

Viskova, L.V. 2009. New species of stenolaemate bryozoans from the Jurassic of the Moscow and Saratov Regions (Russia). Paleontological Journal 43(4), 408-417. DOI 10.1134/S003103010904008X

Walter, B. 1970. Les bryozoaires jurassiques en France. Documents des Laboratoires de Géologie de la Faculté des Sciences de Lyon 35 [for 1969], 1-328.
Wierzbowski, H., Dembicz, K. \& Praszkier, T. 2009. Oxygen and carbon isotope composition of Callovian-lower Oxfordian (Middle-Upper Jurassic) belemnite rostra from central Poland: a record of a late Callovian global sea-level rise? Palaeogeography, Palaeoclimatology, Palaeoecology 283, 182-194. DOI 10.1016/j.palaeo.2009.09.020

Wilson, M.A., Feldman, H.R., Bowen, J.C. \& Avni, Y. 2008. A new equatorial, very shallow marine sclerozoan fauna from the Middle Jurassic (late Callovian) of southern Israel. Palaeogeography, Palaeoclimatology, Palaeoecology 263, 24-29. DOI 10.1016/j.palaeo.2008.01.024

Wilson, M.A., Feldman, H.R. \& Krivicich, E.B. 2010. Bioerosion in an equatorial Middle Jurassic coral-sponge reef community (Callovian, Matmor Formation, southern Israel). Palaeogeography, Palaeoclimatology, Palaeoecology 289, 93-101. DOI 10.1016/j.palaeo.2010.02.019

Wilson, M.A., Reinthal, E.A. \& Ausich, W.I. 2014. Parasitism of a new apiocrinitid crinoid species from the Middle Jurassic (Callovian) of southern Israel. Journal of Paleontology 88, 1212-1221. DOI 10.1666/14-009

Wood, R. 1987. Biology and revised systematics of some Late Mesozoic stromatoporoids. Special Papers in Palaeontology 37, 1-89.

Wood, R. 1999. Reef evolution. 414 pp. Oxford University Press, Oxford.

Zatoń, M., Hara, U., Taylor, P.D. \& Krobicki, M. 2013. Callovian (Middle Jurassic) cyclostome bryozoans from the Zalas Quarry, southern Poland. Bulletin of Geosciences 88(4), 837-863. DOI 10.3140/bull.geosci.1466

Zatoń, M. \& TAYloR, P.D. 2009. Middle Jurassic cyclostome bryozoans from the Polish Jura. Acta Palaeontologica Polonica 54, 267-288. DOI 10.4202/app.2008.0088

ZATOŃ, M. \& TAYLOR, P.D. 2010. Bathonian (Middle Jurassic) cyclostome bryozoans from the Polish Jura. Bulletin of Geosciences 85(2), 275-302. DOI 10.3140/bull.geosci.1184

ZATON, M. \& VinN, O. 2011. Microconchids and the rise of modern encrusting communities. Lethaia 44, 5-7. 